\title{
Pengaruh pertumbuhan ekonomi, upah minimum dan jumlah tenaga kerja terhadap kemiskinan di Kota Jambi Tahun 2000 - 2017
}

\author{
*Fahrur Rozi; Yulmardi; Etik Umiyati
}

\author{
Prodi Ekonomi Pembangunan, Fakultas Ekonomi dan Bisnis, Universitas Jambi \\ *E-mail korespondensi: fahrur1994@gmail.com
}

\begin{abstract}
This study aims to: 1) Know and analyze the development of economic growth, minimum wages, number of workers and poverty levels in Jambi City; and 2) To find out and analyze the influence of economic growth, minimum wages and the number of workers and poverty levels in Jambi City. The analytical tool used in this study is multiple linear regression.The results of this study are that economic growth in Jambi City experienced fluctuations during 2000-2017. The minimum wage in the city of Jambi has increased annually during 2000-2017. Labor in Jambi City experienced fluctuations during 2000-2017. The poverty rate in Jambi City experienced annual fluctuations during 2000-2017. From the results of the processed multiple linear regression that the variable economic growth, minimum wage, labor simultaneously have a significant effect on the level of poverty, it can be seen from the significant value of 0.002 which is smaller than 0.05. While partially the independent variables that influence the poverty level are minimum wages and labor, it can be seen from the significant values smaller than 0.05 .
\end{abstract}

Keywords: Economic Growth, Minimum Wage, Number of Labor, and Poverty Levels.

\begin{abstract}
Abstrak
Penelitian ini bertujuan untuk: 1) Mengetahui dan menganalisis perkembangan pertumbuhan ekonomi, upah minimum, jumlah tenaga kerja dan tingkat kemiskinan di Kota Jambi; dan 2) Untuk mengetahui dan menganalisis pengaruh pertumbuhan ekonomi, upah minimum dan jumlah tenaga kerja dan tingkat kemiskinan di Kota Jambi. Alat analisis yang digunakan dalm penelitian ini yaitu regresi linier berganda. Hasil penelitian ini yaitu pertumbuhan ekonomi di Kota Jambi mengalami fluktuasi selama tahun 2000-2017. Upah minimum di Kota Jambi mengalami peningkatan pertahunnya selama tahun 2000-2017. Tenaga kerja di Kota Jambi mengalami fluktuasi selama tahun 2000-2017. Tingkat kemiskinan di Kota Jambi mengalami fluktuasi pertahunnya selama tahun 2000-2017. Dari hasil olahan regresi linier berganda bahwa variabel pertumbuhan ekonomi, upah minimum, tenaga kerja secara simultan berpengaruh signifikan terhadap tingkat kemiskinan, hal itu terlihat dari nilai signifikan sebesar 0,002 yang lebih kecil dari 0,05. Sedangkan secara parsial variabel bebas yang berpengaruh terhadap tingkat kemiskinan yaitu upah minimum dan tenaga kerja, hal itu terlihat dari nilai signifikan yang lebih kecil dari 0,05.
\end{abstract}

Kata Kunci: Pertumbuhan Ekonomi, Upah Minimum, Jumlah Tenaga Kerja dan Tingkat Kemiskinan. 


\section{PENDAHULUAN}

Kemiskinan merupakan suatu keadaan, sering dihubungkan dengan kebutuhan, kesulitan dan kekurangan di berbagai keadaan hidup. Sebagian orang memahami istilah ini secara subjektif dan komparatif, sementara yang lainnya melihatnya dari segi moral dan evaluatif, dan yang lainnya lagi memahaminya dari sudut ilmiah yang telah mapan. Kemiskinan dipahami dalam berbagai cara. Pemahaman utamanya mencakup gambaran kekurangan materi, gambaran tentang kebutuhan sosial, dan gambaran tentang kurangnya penghasilan dan kekayaan yang memadai (Soebagiyo, 2013).

Permasalahan kemiskinan merupakan masalah yang kompleks dan bersifat multidimensional, oleh karena itu, upaya pengentasan kemiskinan harus dilakukan secara komprehensif, mencakup berbagai aspek kehidupan masyarakat, dan dilaksanakan secara terpadu. Upaya penanggulangan kemiskinan di Kota Jambi dilaksanakan dengan berbagai kebijakan untuk mengurangi/mengatasi kemiskinan melalui pemberdayaan masyarakat dengan Program Nasional Pemberdayaan Masyarakat (PNPM) Mandiri Perkotaan, Usaha Kecil dan Mikro. Hal tersebut dilakukan dengan memberikan pelatihan kepada masyarakat dan memberikan modal usaha kepada masyarakat yang ingin mendirikan usaha. Kemiskinan dapat dilihat dari tingkat pendapatannya untuk memenuhi kebutuhan.

Seseorang termasuk golongan miskin apabila hasil pendapatannya berada di bawah garis kemiskinan tidak cukup untuk memenuhi kebutuhan hidup minimum (Sumodiningrat, 2007). Pertumbuhan ekonomi merupakan salah satu faktor penting untuk lepas dari jerat kemiskinan, karena pertumbuhan ekonomi merupakan gambaran adanya perkembangan ekonomi untuk mencapai tingkat kemakmuran yang lebih baik. Saat ini ekonomi Kota Jambi semakin ke depannya terus mengalami pertumbuhan. Pertumbuhan ekonomi yang tinggi merupakan gambaran terhadap kesejahteraan faktor produksi yang turut serta menciptakan kesejahteraan tersebut, artinya semakin tinggi laju pertumbuhan ekonomi maka semakin tinggi pula produktivitas faktor produksi dan semakin tinggi pula upah yang diterima oleh para pekerja. Suatu perekonomian dikatakan mengalami pertumbuhan atau berkembang apabila tingkat kegiatan ekonomi lebih tinggi daripada apa yang dicapai pada masa sebelumnya Pertumbuhan ekonomi merupakan salah satu tolak ukur bagi kemajuan dan perkembangan suatu bangsa atau pembangunan ekonomi suatu bangsa (Prasetyo, 2009).

Menurut Sukirno (2013) upah adalah pembayaran atas jasa-jasa fisik yang disediakan oleh tenaga kerja kepada para pengusaha. Sedangkan menurut Hasibuan (2016) upah adalah balas jasa yang dibayarkan kepada para pekerja harian dengan berpedoman atas perjanjian yang disepakati membayarnya. Upah yang diberikan ternyata secara riil nilainya sangat rendah meskipun secara nominal angkanya mungkin cukup tinggi. Penetapan upah minimum yang dilakukan oleh pemerintah secara tidak sadar telah membuat para pekerja berada dalam kondisi yang sulit untuk memenuhi kebutuhan sehari-hari (primer) yang semakin hari mengalami fluktuasi harga (inflasi). Kemudian Waluyo (2010) menyebutkan pengaruh antara upah minimum terhadap kemiskinan dipengaruhi oleh adanya biaya sosial inflasi dimana biaya sosial inflasi membuat seorang semakin miskin. Komplain terhadap inflasi adalah hal yang umum, kita tau bahwa kenaikkan dalam daya beli tenaga kerja berasal dari akumulasi modal dan kemajuan teknologi. Biasanya upah tak bergantung pada beberapa banyak uang yang di cetak pemerintah. Jika pemerintah menurunkan inflasi dengan memperlambat pertumbuhan uang. Para pekerja tidak akan melihat upah mereka naik lebih cepat. 
Tenaga kerja biasanya diiringi oleh bertumbuhnya jumlah penduduk, migrasi, kelahiran ataupun kematian. Seiring waktu berjalan pertumbuhannya bisa meningkat dan bisa menurun, pertumbuhan yang tidak diiringi dengan bertumbuhnya lapangan pekerjaan akan menimbulkan efek negatif seperti pengangguran, kriminalitas dan menimbulkan tenaga kerja yang ada di Kota Jambi pindah keluar Kabupaten atau mencari pekerjaan di luar Provinsi Jambi. Sumber daya yang melimpah dan didukung oleh sumber daya alam yang juga melimpah merupakan modal yang sangat besar bagi bangsa Indonesia untuk mengejar ketertinggalannya dari negara lain yang lebih maju dan makmur. Hal ini bisa terwujud kalau pengelolaan SDM dan SDA tadi terlaksana dengan baik, terjadi perimbangan antara pendidikan/skill yang dimiliki oleh tenaga kerja dan ketersediaan lapangan kerja.

Pemerintah sudah melakukan berbagai macam program penanggulangan kemiskinan. Khususnya Pemerintah Provinsi Jambi di Kota Jambi membuat beberapa program yaitu BOS (Bantuan Operasional Sekolah). Raskin (Beras Miskin), BLT (Bantuan Langsung Tunai), Asuransi Miskin, Jamkesmas (Jaminan Kesehatan Masyarakat), PNPM (Program Nasional Pemberdayaan Masyarakat Mandiri) dan Samisake (Satu Milya Satu Kecamatan) yang intinya mengentaskan kemiskinan. Berdasarkan data yang dikutip dari Badan Pusat Statistik (BPS) Kota Jambi bahwa persentase tingkat kemiskinan di Kota Jambi selama 5 tahun terakhir terus berfluktuatif. Pada tahun 2013, persentase tingkat kemiskinan sebesar 9,96\% pada tahun 2014 sebesar 8,94\% selanjutnya pada tahun 2015 kemiskinan di Kota Jambi sebesar 9,67\% kemudian pada tahun 2016 sebesar 8,87\% dan tahun 2017 sebesar 8,84\%. Rata-rata persentase tingkat kemiskinan di Kota Jambi selama periode 2013-2017 sebesar 9.26\% (BPS Kota Jambi, 2017).

Dilihat dari data yang dikutip oleh Badan Pusat Statistik (BPS) Kota Jambi, selama 5 tahun terakhir pada tahun 2013 sampai 2017 pertumbuhan ekonomi terus meningkat. Adapun pertumbuhan ekonomi pada tahun 2013 sebesar 8,5 persen, pada tahun 2014 menjadi 8,17 persen, selanjutnya pada tahun 2015 sebesar 5,56 persen kemudian pada tahun 2016 menjadi 6,81 persen dan pada tahun 2017 pertumbuhan ekonomi sebesar 4,68 persen (BPS Kota Jambi, 2016).

Upah minimum provinsi di Kota Jambi dapat dikatakan masih rendah dibandingkan provinsi - provinsi lain. Pada Tahun 2013 data UMP Kota Jambi sebesar Rp. 1.300.000 pada tahun 2014 meningkat menjadi Rp. 1.502.300, pada tahun 2015 terjadi peningkatan kembali menjadi Rp. 1.710.00, pada tahun 2016 terjadi peningkatan menjadi Rp. 1.906.650 dan pada tahun 2017 sebesar Rp. 2.063.948. Salah satu aspek penting untuk melihat kinerja pembangunan selain Upah Minimum adalah efektivitas penggunaan sumber sumber daya yang ada sehingga lapangan kerja dapat menyerap angkatan kerja yang tersedia. Pertumbuhan ekonomi yang semakin meningkat berarti produksi barang/jasa yang dihasilkan meningkat.

Dengan demikian diperlukan tenaga kerja untuk memproduksi barang/jasa tersebut sehingga pengangguran berkurang dan kemiskinan semakin menurun dimana pada 2013 jumlah tenaga kerja sebanyak 230.243 jiwa lalu megalami peningkatan pada tahun 2014 menjadi 235.722 jiwa, pada tahun 2015 peningkatan terjadi kembali sehingga jumlah tenaga kerja sebanyak 254.351 jiwa dan pada tahun 2016 sebanyak 190.543 jiwa lalu pada tahun 2017 terjadi peningkatan menjadi 268.264 jiwa (BPS Kota Jambi, 2017).

Adapun rumusan masalah dan tujuan yang akan diteliti dalam penelitian ini adalah: (a) mengetahui dan menganalisis perkembangan pertumbuhan ekonomi, upah minimum, jumlah tenaga kerja dan tingkat kemiskinan di Kota Jambi; (b) Mengetahui 
dan menganalisis pengaruh pertumbuhan ekonomi, upah minimum dan jumlah tenaga kerja terhadap tingkat kemiskinan di Kota Jambi tahun 2000-2017.

\section{METODE}

Jenis data yang digunakan dalam penelitian ini adalah Data Sekunder, data sekunder yang dipakai adalah time series (runtut waktu) dari tahun 2000-2017. Sumber data yang dikumpulkan dalam penelitian ini diperoleh dari data publikasi yang diterbitkan intansi pemerintah yaitu Badan Pusat Statistik Kota Jambi. Metode pengumpulan data dalam penelitian ini adalah dengan melakukan studi pustaka dari berbagai literatur, artikel, internet atau bukubuku yang berkaitan dengan permasalahan kemiskinan dan berbagai sumber-sumber lain yang berasal dari instansi-instansi terkait yaitu Badan Pusat Statistik (BPS).

\section{Analisis Deskriptif}

Metode analisis deskriptif adalah suatu metode yang digunakan dalam penelitian langsung mengenai sasaran apa yang hendak diteliti. Alat analisis yang digunakan yaitu analisis regresi linier berganda. Untuk membuktikan tujuan pertama digunakan analisis perkembangan kemiskinan dengan rumus sebagai berikut Badan Pusat Statistik:

$$
\frac{\mathrm{KM}=\mathrm{K}_{\mathrm{t}}-\mathrm{K}_{\mathrm{t}-1} \times 100 \%}{\mathrm{~K}_{\mathrm{t}-1}}
$$

Dimana:

$\begin{array}{ll}\mathrm{KM} & : \text { Perkembangan Kemiskinan } \\ \mathrm{K}_{\mathrm{t}} & : \text { Kemiskinan Tahun Sekarang } \\ \mathrm{K}_{\mathrm{t}-1} & : \text { Kemiskinan Tahun Sebelumnya }\end{array}$

\section{Analisis Kuantitatif}

Analisis kuantitatif yaitu analisis yang dilakukan dengan cara menguji pengaruh antara variabel bebas terhadap variabel terikat. Untuk membuktikan tujuan ketiga, faktor-faktor apa saja yang mempengaruhi tingkat kemiskinan (Gujarati, 1995).

Rumus:

$$
Y=\beta_{0}+\beta_{1} X_{1}+\beta_{2} X_{2}+\beta_{3} X_{3}+e
$$

Kemudian di formulasikan sesuai dengan permasalahan dalam penelitian ini dengan persamaan sebagai berikut:

Dimana:

$$
\mathrm{TKMS}=\beta_{0}+\beta_{1} P E_{t}+\beta_{2} \log U M P_{t}+\beta_{3} \log J T K_{t}+e
$$

$\begin{array}{ll}\text { TKMS } & : \text { Kemiskinan (TKMS) } \\ \beta 0 & : \text { Konstanta } \\ \text { PE } & : \text { Pertumbuhan Ekonomi }\left(P E_{t}\right) \\ \text { Log UMP } & : \text { Log Upah Minimum Provinsi }\left(U M P_{t}\right) \\ \text { Log JTK } & : \text { Log Jumlah Tenaga Kerja }\left(J T K_{t}\right) \\ \beta_{1} \beta_{2} \beta_{3} & : \text { Koefisiensi regresi } \\ e & : \text { Error Term }\end{array}$

\section{Uji Hipotesis}

Terdapat Hasil regresi dilakukan uji hipotesis untuk menguji parameter yang berhasil diduga sebagai petunjuk keberartian dari nilai-nilai yang dihasilkan. Hal ini dilakukan dengan uji statistik yang meliputi (Gujarati, 2015): 


\section{Uji Simultan (Uji F)}

Uji $\mathrm{F}$ digunakan untuk melihat pengaruh dan hubungan seluruh variabel bebas (independent) secara simultan. Bila F-hitung lebih besar dari F-tabel berarti Ho ditolak, artinya variabel $\mathrm{X}_{1}$ secara simultan mampu menjelaskan variabel $\mathrm{Y}$. Tingkat signifikan yang digunakan adalah $\alpha(5 \%$ atau 0,05$)$. Nilai $F$ dapat dihitung dengan menggunakan rumus sebagai berikut (Gujarati, 2015):

Dimana :

$$
\text { F-Hitung }=\frac{\mathrm{R} 2 /(\mathrm{K}-1)}{(1-\mathrm{R} 2) /(\mathrm{n}-\mathrm{k})}
$$

R2 : Koefisien determinasi berganda

$\mathrm{K}$ : Banyaknya paramenter dalam model referensi

$\mathrm{N}$ : Jumlah sampel

(k-1) : Derajat bebas referensi

$(\mathrm{n}-\mathrm{k})$ : Derajat bebas bulat untuk keseluruhan penganggu:

\section{Uji Parsial (Uji T)}

Uji statistik T dilakukan untuk menunjukan seberapa jauh pengaruh satu variabel penjelas atau independen secara individual dalam menerangkan variasi varabel dependen. Untuk menguji hipotesis tersebut digunakan statistik $\mathrm{T}$, dimana nilai $\mathrm{T}$ hitung dapat diperoleh dengan rumus sebagai berikut (Ghozali, 2005):

Dimana:

$$
\mathrm{T} \text { - Hitung }=\frac{\beta \mathrm{i}}{\mathrm{Se}(\beta \mathrm{i})}
$$

$$
\begin{aligned}
& \mathrm{Bi} \quad \text { : Koefisisen Regresi } \\
& \mathrm{Se}(\beta \mathrm{i}): \text { Standart Eror Koefisien Regresi }
\end{aligned}
$$

\section{Koefisien Determinasi $\left(\boldsymbol{R}^{2}\right)$}

Untuk mengetahui respon (kombinasi linier) dari variabel independent (Pertumbuhan ekonomi, upah minimum dan jumlah tenaga kerja) terhadap variabel dependent (Kemiskinan), dapat dilakukan perhitungan determinasi $\left(\mathrm{R}^{2}\right)$ dengan menggunakan perhitungan komputer atau softwere statistik SPSS versi 20, secara ekonometrika nilai $\mathrm{R}^{2}$ yang semakin mendekati 1 berarti nilainya semakin tepat menaksir garis linier tersebut (Gujarati, 2015).

Rumus:

Dimana:

$$
\mathrm{R}^{2}=\frac{1-(1-r 2) n-1}{n-k}
$$

$$
\begin{array}{ll}
\mathrm{R}^{2} & \text { : Koefisien Determinasi Berganda } \\
\mathrm{R} & \text { : Koefisien Korelasi } \\
\mathrm{N} & \text { : Jumlah Sample } \\
\mathrm{K} & \text { : Banyaknya Parameter Dalam Model Regresi Nilainya 0 }
\end{array}
$$

\section{Uji Asumsi Klasik}

Pengujian model terhadap asumsi klasik diberlakukan pada persamaan struktural yang meliputi Uji Normalitas, Uji Multikolinearitas, Uji Autokorelasi dan Uji Heterokedasitas: 


\section{Uji Normalitas}

Uji normalitas bertujuan untuk melihat apakah residualnya terdistribusi secara normal atau tidak dengan asumsi model regresi yang Best Linear Unbias Estimator (BLUE) dari klasik adalah dengan membandingkan nilai Jarque-Berra dengan nilai ChiSquare $\left(X^{2}\right)$. Jika nilai Jarque-Berra lebih kecil dari nilai tabel Chi-Square $\left(X^{2}\right)$, maka dikatakan model lolos dari ketidaknormalan distribusi residualnya (Insukindro, 2004).

\section{Uji Multikolinearitas}

Multikolinieritas adalah adanya hubungan (sempurna atau tidak sempurna) diantara beberapa atau semua variabel independen dalam model regresi. Jika multikolinearitas tidak sempurna maka koefisien regresi tidak dapat ditentukan. Jika multikolinearitas tidak sempurna maka koefisien regresi tidak memilki ketepatan yang tinggi. Sebuah model yang mengandung multikolinieritas dapat ditunjukkan oleh indikasi sebagai berikut: (Gujarati, 1995) (a) $R^{2}$ tinggi, tetapi sedikit t statistic yang signifikan; (b) Adanya korelasi yang tinggi antara variabel.

\section{Uji Autokorelasi}

Autokorelasi adalah korelasi (hubungan) yang terjadi antara anggota-anggota dari serangkaian pengamatan yang tersusun dalam rangkaian waktu (time series). Autokorelasi ini menunjukkan hubungan antara nilai-nilai yang berurutan dari variabel yang sama. Autokorelasi dapat terjadi apabila kesalahan pengganggu suatu periode korelasi dengan kesalahan penggangu periode sebelumnya. Pengujian autokorelasi dilakukan dengan eviews, alat yang digunakan adalah Breusch-Godfrey serial Correlation LM test. Jika nilaia Obs*R-square hasil pengujian serial Correlation LM test lebih kecil dari nilai tabel Chi-Square $\left(X^{2}\right)$ maka lolos dari adanya autokorelasi (Insukindro, 2004).

\section{Uji Heterokedasitas}

Uji heteroskedarisitas dilakukan untuk menguji apakah dalam sebuah model regresi terjadi ketidaksamaan varians dari residual pengamatan satu ke residual kepengamatan yang lain tetap, maka telah terja di heteroskedatisitas. Regresi yang baik adalah yang tidak terjadi heteroskedastisitas. Heteroskedastisitas terjadi bila variabel gangguan mempunyai varibael yang sama untuk observasi, untuk mendeteksi ada atau tidaknya heteroskedastisitas digunakan uji White's heteroskedastisitas test. Jika nilai Chi-Square hitung lebih kecil dari nilai Chi-Square tabel $\left(X^{2}\right)$ menunjukkan tidak adanya heteroskedastisitas (Gujarati, 2015).

\section{HASIL DAN PEMBAHASAN}

\section{Pertumbuhan Ekonomi di Kota Jambi}

Menurut Todaro, Michael P. Smith, dan Stephen C. (2012) pertumbuhan ekonomi diartikan sebagai kenaikan kapasitas dalam jangka panjang dari negara yang bersangkutan untuk menyediakan berbagai barang ekonomi kepada penduduknya. Berikut ini dapat dilihat pertumbuhan ekonomi di Kota Jambi selama tahun 2000 sampai 2017 pada tabel berikut ini: 
Tabel 1. Pertumbuhan Ekonomi di Kota Jambi Tahun 2000-2017

\begin{tabular}{cc}
\hline Tahun & Pertumbuhan Ekonomi (\%) \\
\hline 2000 & 4,81 \\
2001 & 5,28 \\
2002 & 3,68 \\
2003 & 4,85 \\
2004 & 5,16 \\
2005 & 5,69 \\
2006 & 5,93 \\
2007 & 6,14 \\
2008 & 6,14 \\
2009 & 6,47 \\
2010 & 6,66 \\
2011 & 6,97 \\
2012 & 7,67 \\
2013 & 8,50 \\
2014 & 8,17 \\
2015 & 5,56 \\
2016 & 6,81 \\
2017 & 4,68 \\
\hline Rata-Rata & $\mathbf{6 , 1 4}$
\end{tabular}

Sumber: Badan Pusat Statistik, 2018 (diolah)

Berdasarkan Tabel 1, dapat dilihat bahwa pertumbuhan ekonomi Kota Jambi selama tahun 2000-2017 mengalami fluktuasi setiap tahunnya. Rata-rata pertumbuhan ekonomi Kota Jambi selama 18 tahun terakhir adalah 6,14 persen. Rata-rata pertumbuhan tersebut di Kota Jambi jika dibandingkan dengan rata-rata pertumbuhan ekonomi Provinsi Jambi pada periode yang sama angka rata-ratanya sebesar 6,35 persen hanya selisih 0,21 persen. Pertumbuhan ekonomi tertinggi tercatat pada tahun 2013 yaitu sebesar 8,5 persen. Tingginya pertumbuhan ekonomi pada tahun 2013 terjadi karena meningkatnya sektor unggulan PDRB yaitu pada sektor penyediaan akomodasi makanan dan minum dengan signifikan yaitu dari 6,4 persen menjadi 18,73 persen. Sedangkan pertumbuhan ekonomi terendah tercatat pada tahun 2002 yaitu 3,68 persen. Rendahnya pertumbuhan ekonomi pada tahun 2012 dikarenakan turunnya produksi pada hampir seluruh sektor PDRB. Turunnya produksi dikarenakan anjloknya konsumsi rumah tangga, konsumsi rumah tangga hanya mampu tumbuh 3,28 persen.

\section{Perkembangan Upah Minimum}

Upah minimum merupakan hak pekerja/buruh yang diterima dan dinyatakan dalam bentuk uang sebagai imbalan dari pengusaha atau pemberi kerja kepada pekerja/buruh yang ditetapkan dan dibayarkan menurut suatu perjanjian kerja, kesepakatan atau peraturan perundang undangan termasuk tunjangan bagi pekerja/buruh dan keluarganya atas suatu pekerjaan atau jasa yang telah dilakukan. Dibawah ini dijelaskan Upah minimum di Kota Jambi periode 2000-2017: 
Tabel 2. Upah minimum di Kota Jambi periode 2000-2017

\begin{tabular}{ccc}
\hline Tahun & Upah Minimum (Rupiah) & Perkembangan (\%) \\
\hline 2000 & 173.000 & - \\
2001 & 245.000 & 41,61 \\
2002 & 304.000 & 24,08 \\
2003 & 390.000 & 28,28 \\
2004 & 425.000 & 8,97 \\
2005 & 485.000 & 14,11 \\
2006 & 563.000 & 16,08 \\
2007 & 658.000 & 16,87 \\
2008 & 724.000 & 10,03 \\
2009 & 800.000 & 10,49 \\
2010 & 900.000 & 12,5 \\
2011 & 1.028 .000 & 14,22 \\
2012 & 1.142 .500 & 11.08 \\
2013 & 1.300 .000 & 13.83 \\
2014 & 1.502 .230 & 15,53 \\
2015 & 1.710 .000 & 13,84 \\
2016 & 1.906 .000 & 11,46 \\
2017 & 2.063 .948 & 8,23 \\
\hline Rata-Rata & & $\mathbf{1 5 , 9 5}$ \\
\hline
\end{tabular}

Sumber: Badan Pusat Statistik, 2018 (diolah)

Berdasarkan Tabel 2, upah minimum di Provinsi Jambi terus mengalami peningkatan setiap tahunnya, namun perkembangannya masih berfluktuasi. Rata-rata perkembangan upah minimum Provinsi Jambi selama tahun 2000-2017 yaitu sebesar 15,95 persen.

Perkembangan upah minimum tertinggi tercatat pada tahun 2001 dengan perkembangan upah minimum sebesar 41,61 persen. Pada tahun 2001 upah minimum yang ditetapkan untuk Provinsi Jambi sebesar Rp. 245.000, nilai upah minimum ini naik dari tahun sebelumnya sebesar Rp. 72.000. Sementara perkembangan terendah tercatat pada tahun 2017 yaitu sebesar 8,23 persen. Pada tahun 2017 upah minimum yang ditetapkan untuk Provinsi Jambi sebesar Rp. 2.063 .948 hanya naik dari tahun sebelumnya sebesar Rp. 157.948. Rendahnya perkembangan tersebut disebabkan oleh keputusan Pemerintah Provinsi Jambi berdasarkan pertimbangan asumsi inflasi di Jambi sebesar 3,07 persen dan pertumbuhan ekonomi tahun 2017 sebesar 5,1 persen.

\section{Perkembangan Tenaga Kerja}

Tenaga kerja merupakan tiap orang yang mampu melaksanakan pekerjaan baik di dalam maupun di luar hubungan kerja guna menghasilkan barang dan jasa untuk memenuhi kebutuhan masyarakat. Tenaga kerja yang disebut dengan Penduduk Usia Kerja (PUK) terdiri dari angkatan kerja dan bukan angkatan kerja. Angkatan kerja mencakup penduduk yang bekerja maupun yang sedang mencari pekerjaan. Penduduk yang bekerja dibagi menjadi dua, yaitu penduduk yang bekerja penuh dan setengah menganggur. Sastrohadiwiryo dalam Rezky (2015) mengatakan tenaga kerja adalah salah satu unsur yang memiliki peran sangat penting dalam oprasional perusahaan, oleh karna itu unsur tenaga kerja tidak dapat dilepaskan dari unsur lainnya, dimana untuk mewujudkan tujuan yang diharapkan dalam suatu proses kerja diperlukan peran tenaga kerja. Dibawah ini dijelaskan tenaga kerja di Kota Jambi periode 2000-2017: 
Tabel 3. Tenaga kerja di Kota Jambi periode 2000-2017

\begin{tabular}{ccc}
\hline Tahun & Tenaga Kerja (Jiwa) & Perkembangan $(\%)$ \\
\hline 2000 & 98.450 & - \\
2001 & 143.250 & 45,50 \\
2002 & 121.925 & $-14,88$ \\
2003 & 154.876 & 27,02 \\
2004 & 176.992 & 14,27 \\
2005 & 172.025 & $-2,80$ \\
2006 & 182.102 & 5,85 \\
2007 & 176.688 & $-2,97$ \\
2008 & 191.661 & 8,47 \\
2009 & 195.868 & 2,19 \\
2010 & 218.401 & 11,50 \\
2011 & 238.307 & 9,11 \\
2012 & 226.607 & $-4,90$ \\
2013 & 230.243 & 1,60 \\
2014 & 235.722 & 2,37 \\
2015 & 254.351 & 7,90 \\
2016 & 190.543 & $-25,08$ \\
2017 & 268.264 & 40,78 \\
\hline Rata-Rata & & $\mathbf{6 , 9 9}$ \\
\hline
\end{tabular}

Sumber: Badan Pusat Statistik, 2018 (diolah)

Berdasarkan Tabel 3, menjelaskan bahwa periode 2000-2017 tenaga kerja di Kota Jambi mengalami fluktuasi, dengan rata-rata perkembangan sebesar 6,99\% pertahunnya. Peningkatan terbesar terjadi pada tahun 2001 sebesar 45,40\% dari tahun sebelumnya, Sedangkan peningkatan terkecil terjadi pada tahun 2016 sebesar -25,08\%. Berdasarkan data ini menggambarkan bahwa kondisi ketenagakerjaan di Kota Jambi masih sangat memerlukan perhatian. Hal ini karena kesempatan kerja yang meningkat ternyata diiringi dengan peningkatan angkatan kerja yang mencari pekerjaan oleh karena itu, pembangunan aspek ketenagakerjaan harus terus dilakukan.

\section{Perkembangan Tingkat Kemiskinan}

Kemiskinan merupakan sejumlah penduduk yang tidak mampu mendapatkan sumber daya yang cukup untuk memenuhi kebutuhan dasar. Penyebab kemiskinan bermuara pada teori lingkaran setan kemiskinan. Adanya keterbelakangan, ketidaksempurnaan pasar, dan kurangnya modal menyebabkan rendahnya produktivitas. Rendahnya produktivitas menyebabkan rendahnya pendapatan yang mereka terima. Rendahnya pendapatan akan berimplikasi pada rendahnya tabungan dan investasi. Rendahnya investasi berakibat pada keterbelakangan. Berbagai program telah dilakukan untuk mengatasi persoalan tersebut, tetapi secara statistik angka kemiskinan cenderung semakin tinggi seiring dengan meningkat nya tingkat kebutuhan masyarakat. Rendahnya tingkat kehidupan yang sering dijadikan sebagai alat ukur kemiskinan hanyalah merupakan salah satu mata rantai dalam lingkaran kemiskinan. Banyak tokoh, peneliti, badan resmi pemerintah, yang memiliki pendapat tersendiri dalam memandang masalah kemiskinan ini. Dibawah ini dijelaskan Kemiskinan di Kota Jambi periode 2000-2017: 
Tabel 4. Tingkat kemiskinan di Kota Jambi periode 2000-2017

\begin{tabular}{cccc}
\hline Tahun & $\begin{array}{c}\text { Penduduk } \\
\text { Miskin (Orang) }\end{array}$ & $\begin{array}{c}\text { Tingkat Kemiskinan } \\
(\boldsymbol{\%})\end{array}$ & $\begin{array}{c}\text { Perkembangan } \\
\text { Penduduk Miskin } \\
(\boldsymbol{\%})\end{array}$ \\
\hline 2000 & 73.648 & 4,21 & - \\
2001 & 80.382 & 4,9 & 9,14 \\
2002 & 96.512 & 5,32 & 20,07 \\
2003 & 105.888 & 6,26 & 9,71 \\
2004 & 108.725 & 6,04 & 2,68 \\
2005 & 117.365 & 5,37 & 7,95 \\
2006 & 146.837 & 5,18 & 25,11 \\
2007 & 161.831 & 5,04 & 10,21 \\
2008 & 179.835 & 11,63 & 11,13 \\
2009 & 192.354 & 10,54 & 6,96 \\
2010 & 213.395 & 9,9 & 10,94 \\
2011 & 223.181 & 9,27 & 4,59 \\
2012 & 240.441 & 9,8 & 7,73 \\
2013 & 275.779 & 9,96 & 14,70 \\
2014 & 296.681 & 8,94 & 7,58 \\
2015 & 333.034 & 9,67 & 12,25 \\
2016 & 350.420 & 8,87 & 5,22 \\
2017 & 370.910 & 8,84 & 5,85 \\
\hline Rata-Rata & & & $\mathbf{1 0 , 1 1}$ \\
\hline
\end{tabular}

Sumber: Badan Pusat Statistik, 2018 (diolah)

Dilihat dari Tabel 4, menjelaskan bahwa periode 2000-2017 perkembangan penduduk miskin di Kota Jambi cenderung mengalami peningkatan setiap tahunnya, rata-rata perkembangan penduduk miskinnya sebesar sebesar 10,11 persen pertahunnya. Peningkatan terbesar terjadi pada tahun 2006 sebesar 25,11 persen dari tahun sebelumnya. Sedangkan perkembangan terendah terjadi pada tahun 2004 sebesar 2,68 persen. Berdasarkan data ini menggambarkan bahwa kondisi tingkat kemiskinan di Kota Jambi masih sangat memerlukan perhatian. Hal ini karena kemiskinan harus dikurangi setiap tahunnya dengan program-program pengantasan kemiskinan dari pemerintah.

Permodelan dalam menggunakan tekni regresi linear berganda yang menggunakan model pendekatan OLS (Ordinary Least Square). Berikut ini hasil olah dengan menggunakan alat analisis SPSS versi 20:

Tabel 5. Hasil analisis regresi linear berganda

\begin{tabular}{|c|c|c|c|c|c|c|}
\hline \multicolumn{7}{|c|}{ Coefficients $^{\mathrm{a}}$} \\
\hline & \multirow[b]{2}{*}{ Model } & \multicolumn{2}{|c|}{$\begin{array}{l}\text { Unstandardized } \\
\text { Coefficients }\end{array}$} & \multirow{2}{*}{$\begin{array}{c}\text { Standardized } \\
\text { Coefficients } \\
\text { Beta }\end{array}$} & \multirow[b]{2}{*}{$\mathbf{t}$} & \multirow[b]{2}{*}{ Sig. } \\
\hline & & B & $\begin{array}{l}\text { Std. } \\
\text { Error }\end{array}$ & & & \\
\hline \multirow[t]{4}{*}{1} & (Constant) & 1.251 & .206 & & 6.082 & .000 \\
\hline & $\begin{array}{l}\text { Pertumbuhan } \\
\text { Ekonomi }\end{array}$ & .206 & .280 & .088 & .737 & .473 \\
\hline & Upah Minimum & .076 & .017 & .598 & 4.595 & .000 \\
\hline & Tenaga Kerja & .608 & .216 & .370 & 2.812 & .014 \\
\hline
\end{tabular}


a. Dependent Variable: Tingkat Kemiskinan

Sumber: Data diolah, 2019

Dilihat dari Tabel 5, hasil pengolahan data dengan pendekatan OLS (Ordinary Least Square) sebagai berikut:

$$
\text { TKMS }=1,251+0,206 \mathrm{PE}+0,076 \log \mathrm{UMP}+0,608 \operatorname{LogJTK}+\mathrm{e}
$$

Berdasarkan model estimasi dengan pendekatan OLS (Ordinary Least Square) maka dapat dijelaskan beberapa hal sebagai berikut: (1) Nilai constanta sebesar 1,251, artinya jika pertumbuhan ekonomi (PE), upah minimum (LogUMP) dan tenaga kerja (LogJTK) tidak mengalami perubahan atau tetap, maka tingkat kemiskinan (TKMS) sebesar 1,251 persen; (2) Koefisien regresi variable pertumbuhan ekonomi (PE) sebesar 0,206 artinya, jika pertumbuhan ekonomi (PE) naik satu persen maka tingkat kemiskinan (TKMS) akan meningkat sebesar 0,206 persen; (3) Koefisien regresi variable upah minimum (LogUMP) sebesar 0,076 artinya, jika upah minimum (LogUMP) naik satu persen maka tingkat kemiskinan (TKMS) akan meningkat sebesar 0,076 persen; (4) Koefisien regresi variable tenaga kerja (LogJTK) sebesar 0,608 artinya, jika tenaga kerja (LogJTK) naik satu persen maka tingkat kemiskinan (TKMS) akan meningkat sebesar 0,608 persen.

Pada tabel berikut ini dapat dilihat hasil uji $\mathrm{F}$ yang diolah dengan menggunakan SPSS versi 20:

Tabel 6. Hasil uji simultan (Uji F)

\begin{tabular}{|c|c|c|c|c|c|c|}
\hline \multicolumn{7}{|c|}{ ANOVA $^{a}$} \\
\hline & Model & $\begin{array}{c}\text { Sum of } \\
\text { Squares }\end{array}$ & Df & $\begin{array}{c}\text { Mean } \\
\text { Square }\end{array}$ & $\mathbf{F}$ & Sig. \\
\hline \multirow[t]{3}{*}{1} & Regression & .740 & 3 & .247 & 29.755 & $.000^{\mathrm{b}}$ \\
\hline & Residual & .116 & 14 & .008 & & \\
\hline & Total & .856 & 17 & & & \\
\hline
\end{tabular}

a. Dependent Variable: Tingkat Kemiskinan

b. Predictors: (Constant), Tenaga Kerja, Pertumbuhan Ekonomi, Upah Minimum Sumber: Data diolah, 2019

Dari Tabel 6, pengujian ini dilakukan dengan cara membandingkan nilai $\mathrm{F}$ hitung dan $\mathrm{F}$ tabel. Untuk mencari nilai $\mathrm{F}$ tabel maka digunakan rumus (n-k-1 atau 18-3$1=14$ ) dengan tingkat signifikan $0,05 \%$. Hasil yang diperoleh yaitu sebesar 3,34. Dari tabel Anova diperoleh nilai $\mathrm{F}$ hitung sebesar 29,755 dengan signifikansi sebesar 0,000. Hal ini menunjukkan bahwa nilai $F$ hitung lebih besar dari nilai $F$ tabel $(29,755>3,34)$ dan nilai signifikan lebih kecil dari nilai $\alpha(0,000<0,05)$, maka dapat disimpulkan bahwa secara simultan pertumbuhan ekonomi $\left(\mathrm{X}_{1}\right)$, upah minimum $\left(\mathrm{X}_{2}\right)$ dan tenaga kerja $\left(\mathrm{X}_{3}\right)$ berpengaruh signifikan terhadap kemiskinan $(\mathrm{Y})$.

Tabel 7. Hasil uji parsial (Uji t)

\section{Coefficients $^{\mathrm{a}}$}

\begin{tabular}{|c|c|c|c|c|c|c|}
\hline & & $\begin{array}{l}\text { Unstan } \\
\text { Coeffic }\end{array}$ & $\begin{array}{l}\text { ardized } \\
\text { nts }\end{array}$ & $\begin{array}{l}\text { Standardizec } \\
\text { Coefficients }\end{array}$ & & \\
\hline & Model & B & $\begin{array}{c}\text { Std. } \\
\text { Error }\end{array}$ & Beta & $\mathbf{T}$ & Sig. \\
\hline 1 & (Constant) & 1.251 & .206 & & 6.082 & .000 \\
\hline
\end{tabular}




\begin{tabular}{llllll} 
Pertumbuhan & .206 & .280 & .088 & .737 & .473 \\
Ekonomi & & & .598 & 4.595 & .000 \\
Upah Minimum & .076 & .017 & .670 \\
Tenaga Kerja & .608 & .216 & .370 & 2.812 & .014 \\
\hline
\end{tabular}

a. Dependent Variable: Tingkat Kemiskinan

Sumber: Data diolah, 2019

Dilihat dari Tabel 7 diatas, dapat dijelaskan beberapa hal berikut ini:

\section{Pertumbuhan Ekonomi (PE)}

Untuk variabel nilai pertumbuhan ekonomi diperoleh nilai t hitung sebesar 0,737 dengan tingkat signifikan sebesar 0,473. Hal ini menunjukkan bahwa nilai t hitung lebih kecil daripada nilai t tabel $(0,737<2,144)$ dan nilai signifikan lebih besar daripada $\alpha$ $(0,473>0,05)$. Hasil dari uji regresi menunjukkan bahwa secara parsial pertumbuhan ekonomi tidak berpengaruh terhadap kemiskinan.

\section{Upah Minimum (LogUMP)}

Untuk variabel upah minimum diperoleh nilait hitung sebesar 4.595 dengan tingkat signifikan sebesar 0,000. Hal ini menunjukkan bahwa nilai t hitung lebih besar daripada nilai t tabel $(4.595>2,144)$ dan nilai signifikan lebih kecil daripada $\alpha(0,000<$ $0,05)$ Hasil ini menunjukkan bahwa secara parsial upah minimum berpengaruh terhadap kemiskinan.

\section{Tenaga Kerja (LogJTK)}

Untuk variabel tenaga kerja diperoleh nilai t hitung sebesar 2.812 dengan tingkat signifikan sebesar 0,014. Hal ini menunjukkan bahwa nilai t hitung lebih besar daripada nilai $t$ tabel $(2.812>2,144)$ dan nilai signifikan lebih kecil daripada $\alpha(0,014<0,05)$. Hasil dari uji ini menunjukkan bahwa secara parsial tenaga kerja berpengaruh terhadap kemiskinan.

Untuk mengetahui besarnya persentase pengaruh variabel bebas (independen) terhadap variabel terikat (dependen) yang dapat dilihat dari tabel berikut ini:

Tabel 8. Hasil uji determinasi $\left(\mathrm{R}^{2}\right)$

Model Summary ${ }^{b}$

\begin{tabular}{ccccc}
\hline Model & R & R Square & $\begin{array}{c}\text { Adjusted R } \\
\text { Square }\end{array}$ & Durbin-Watson \\
\hline 1 & $.930^{\mathrm{a}}$ & .864 & .835 & .938 \\
\hline
\end{tabular}

a. Predictors: (Constant), Tenaga Kerja, Pertumbuhan Ekonomi, Upah Minimum Sumber: Data diolah, 2019

Dari Tabel 8, korelasi yang ditunjukan dengan nilai $\mathrm{R}$ sebesar 0,930 artinya variabel pertumbuhan ekonomi, upah minimum dan tenaga kerja mempunyai hubungan yang sangat erat dalam mempengaruhi kemiskinan. Nilai $\mathrm{R}$ Square $=0,864$ dapat diartikan besarnya pertumbuhan ekonomi, upah minimum dan tenaga kerja mampu mempengaruhi kemiskinan sebesar $86,4 \%$ sedangkan sisanya sebesar $13,6 \%$ dipengaruhi atau dijelaskan oleh variabel lain yang tidak termasuk dalam penelitian ini.

\section{Analisis Ekonomi}

Kemiskinan merupakan salah satu faktor ekonomis masalah sosial yang banyak terjadi yang disebabkan oleh keadaan ekonomi keluarga yang kurang mendukung. Besarnya pengaruh kemiskinan tentunya dipengaruhi oleh banyak faktor. Dalam 
penelitian ini penulis menilai bahwa pengaruh pertumbuhan ekonomi, upah minimum dan tenaga kerja dalam mempengaruhi kemiskinan di Kota Jambi cukup besar.

Pertumbuhan ekonomi memiliki pengaruh positif dan tidak signifikan terhadap kemiskinan dan hubungan tersebut bersifat positif dan searah. Hal ini disebabkan peningkatan PDRB yang tidak melibatkan penduduk miskin, seharusnya penduduk miskin dilibatkan sebagai tenaga produksi. Melibatkan penduduk miskin dalam produksi artinya penduduk miskin mendapatkan pekerjaan dan mendapatkan upah, dengan mendapat upah maka penduduk miskin akan dapat mencukupi kebutuhannya sehingga penduduk tersebut terhindar dari kemiskinan.

Upah minimum berpengaruh positif dan signifikan terhadap tingkat kemiskinan dan hubungan tersebut bersifat positif dan searah, artinya ketika upah minimum meningkat maka tingkat kemiskinan ikut meningkat. Hal ini disebabkan karena upah yang diterima tidak dapat menutupi kebutuhan pangan keluarga, oleh sebab itu pemerintah Kota Jambi harus terus memperhatikan angka kelahiran supaya kebutuhan dalam satu keluarga dapat tercukupi dengan upah minimum yang telah ditetapkan pemerintah.

Tenaga kerja berpengaruh positif dan signfikan terhadap tingkat kemiskinan dan hubungan tersebut bersifat positif dan searah. Oleh sebab itu, pemerintah Kota Jambi harus memperbanyak lapangan usaha. Sebab, dengan memperbanyak lapangan usaha akan membuka lapangan kerja dan para tenaga kerja dari masyarakat miskin dapat menambah penghasilan sehingga tingkat kemiskinan berkurang.

Berdasarkan hasil penelitian ini, maka penelitian ini membutuhkan implikasi kebijakan yaitu sebagai berikut: (1) Pemerintah Kota Jambi harus mengawasi perusahaan dalam memberikan upah terhadap karyawan sesuai dengan ketetapan upah minimum yang berlaku pada tahun tersebut sehingga penduduk miskin yang bekerja akan lebih sejahtera karena mendapatkan upah yang sesuai atau layak untuk membiayai kebutuhan; (2) Pemerintah Kota Jambi juga harus memperluas kesempatan kerja bagi pengangguran karena pengurangan pengangguran akan mengurangi tingkat kemiskinan; (3) Pemerintah Kota Jambi seharusnya memberi himbauan kepada perusahaanperusahaan agar menyerap penduduk miskin sebagai tenaga produksi seiring dengan peningkatan produksi perusahaan tersebut, tentunya kebijakan ini akan dapat mengentasi kemiskinan di Kota Jambi; (4) Pemerintah Kota Jambi seharusnya memperbesar anggaran untuk memberi subsidi masyarakat miskin dalam membeli kebutuhan pokok atau memberikan kepada penduduk miskin berupa beasiswa agar penduduk miskin dapat melanjutkan pendidikannya.

\section{KESIMPULAN DAN SARAN}

\section{Kesimpulan}

Berdasarkan pembahasan pada bab-bab sebelumnya, maka dapat ditarik beberapa kesimpulan bahwasannya Pertumbuhan ekonomi di Kota Jambi mengalami fluktuasi selama tahun 2000-2017. Upah minimum di Kota Jambi mengalami peningkatan pertahunnya selama tahun 2000-2017. Tenaga kerja di Kota Jambi mengalami fluktuasi selama tahun 2000-2017. Tingkat kemiskinan di Kota Jambi mengalami fluktuasi pertahunnya selama tahun 2000-2017. Dari hasil penelitian variabel pertumbuhan ekonomi, upah minimum, tenaga kerja secara simultan berpengaruh signifikan terhadap tingkat kemiskinan, hal itu terlihat dari nilai signifikan sebesar 0,002 yang lebih kecil dari 0,05. Sedangkan secara parsial variabel bebas yang berpengaruh terhadap tingkat kemiskinan yaitu upah minimum dan tenaga kerja, hal itu 
terlihat dari nilai signifikan yang lebih kecil dari 0,05.

\section{Saran}

Dari penelitian tersebut penulis dapat memberikan beberapa saran yaitu, Tingkat kemiskinan di Kota Jambi mengalami fluktuasi hal ini disebabkan karena pertumbuhan ekonomi dan tenaga kerja mengalami fluktuasi. Seharusnya pemerintah Kota Jambi dapat meningkatkan pertumbuhan ekonomi setiap tahunnya dengan meningkatkan produksi seluruh sektor secara merata dan meningkatkan tenaga kerja dengan membuka kesempatan kerja yang seluas-luasnya. Serta berdasarkan hasil penelitian bahwa yang berpengaruh signfikan terhadap tingkat kemiskinan yaitu upah minimum dan tenaga kerja. Saran untuk pemerintah Kota Jambi yaitu mengawasi perusahaan dalam memberikan upah terhadap karyawan sesuai dengan ketetapan upah minimum yang berlaku pada tahun tersebut sehingga penduduk miskin yang bekerja akan lebih sejahtera karena mendapatkan upah yang sesuai atau layak untuk membiayai kebutuhan. Pemerintah Kota Jambi juga harus memperluas kesempatan kerja bagi pengangguran karena pengurangan pengangguran akan mengurangi tingkat kemiskinan.

\section{DAFTAR PUSTAKA}

Badan Pusat Statistik. (2016). Kemiskinan, Jambi Dalam Angka, Publikasi Tahunan Badan Pusat Statistik Provinsi Jambi tahun 2005-2016. Badan Pusat Statistik: Jambi.

Badan Pusat Statistik. (2017). PDRB Kota Jambi, Kota Jambi Dalam Angka, Berbagai Edisi. Badan Pusat Statistik: Jambi.

Ghozali. (2005). Ekonometrika Teori, Konsep dan Aplikasi SPSS 17. Universitas Diponegoro: Semarang.

Gujarati. (1995). Basic Econometric $5^{\text {th }}$ Edition. McGraw-Hill: New York.

Gujarati. (2015). Dasar-Dasar Ekonometrika Buku 2. Raden Carlos Mangusong (Penj). Salemba Empat: Jakarta.

Hasibuan. (2016). Ekonomi Pembangunan dan Perekonomian Indonesia. Armico: Bandung.

Insukindro. (2004). Modul Ekonometrika Dasar. UGM: Yogyakarta.

Prasetyo, P.Eko. (2009). Fundamental Makro Ekonomi. Beta Offset: Yogyakarta.

Sastrohadiwiryo, (2015). Manajemen Tenaga Kerja Indonesia, Pendekatan Administratif dan Operasional. Bumi Aksara: Jakarta.

Soebagiyo, Daryono. (2013). Perekonomian Indonesia Universitas Muhammadiyah Surakarta: Surakarta.

Sukirno, Sadono. (2013). Ekonomi Pembangunan Proses, Masalah Dasar Kebijakan pembangunan.

Sumodiningrat, Gunawan. (2007). Kajian Ringkas Tentang Pembangunan Manusia Indonesia, Kompas: Jakarta.

Todaro, Michael P. Smith, dan Stephen C. (2012). Economic Development (the $11^{\text {th }}$ edition). Boston: Pearson Addison Wesley.

Waluyo. (2010). Dampak Desentralisasi Fiskal Terhadap Pertumbuhan Ekonomi dan Ketimpangan dalam Implementasi Otonomi Daerah di Provinsi Jambi. Jurnal Paradigma Ekonomika. 1 (5), 4-8. 